Research Institute for Quantitative Studies in Economics and Population Faculty of Social Sciences, McMaster University

Hamilton, Ontario, Canada

L8S 4M4

\title{
THE EFFECT OF MARGINAL TAX RATES ON TAXABLE INCOME: A PANEL STUDY OF THE 1988 \\ TAX FLATTENING IN CANADA
}

Mary-Anne Sillamaa

Michael R. Veall

QSEP Research Report No. 354

August 2000

Michael Veall is a QSEP Research Associate and a member of the McMaster Department of Economics. Mary-Anne Sillamaa is with Statistics Canada.

This report is cross-listed as No. 25 in the McMaster University SEDAP Research Paper Series.

The Research Institute for Quantitative Studies in Economics and Population (QSEP) is an interdisciplinary institute established at McMaster University to encourage and facilitate theoretical and empirical studies in economics, population, and related fields. For further information about QSEP and other reports in this series, see our web site http://socserv2.mcmaster.ca/ qsep. The Research Report series provides a vehicle for distributing the results of studies undertaken by QSEP associates. Authors take full responsibility for all expressions of opinion. 


\title{
The Effect of Marginal Tax Rates on Taxable Income:
}

\section{A Panel Study of the 1988 Tax Flattening in Canada}

\author{
Mary-Anne Sillamaa \\ Statistics Canada \\ Michael R. Veall \\ SEDAP and McMaster University
}

\begin{abstract}
Federal tax reform in 1988 flattened the Canadian personal income tax schedule, changing the marginal tax rates for many individuals. Using methods similar to those applied by Auten and Carroll (1999) in the study of the effects of the 1986 U.S. Tax Reform Act, we estimate the responsiveness of income to changes in taxes to be substantially smaller in Canada. However we find evidence of a much higher response in self-employment income, in the labour income of seniors and from those with high incomes.
\end{abstract}

JEL Code: H24, Personal income and other nonbusiness taxes and subsidies

Key Words: Marginal tax rate effects on taxable income, tax avoidance

Corresponding author: Michael R. Veall,

Department of Economics and SEDAP, McMaster University, Hamilton, Ontario, Canada, L8S 4M4.

phone: $1-905-525-9140 \times 23829$

FAX: 1-905-521-8232

email: veall@mcmaster.ca 


\section{Introduction}

Canada undertook a major personal income tax reform in 1988. While changes in marginal tax rates were not as substantial as they were in either of the United States tax reforms of 1981or 1986, it nonetheless seems remiss that the effects have not been widely studied. This is in sharp contrast to the literature on U.S. tax reform: see for example the survey of Auerbach and Slemrod (1997) and the book edited by Slemrod (1990). Our goal is to determine what can be learned from the Canadian experience, in particular with respect to estimation of the response of taxable income to changes in tax rates.

The responsiveness of taxable income to changes in tax rates (henceforward, the "taxprice elasticity") has been a particular focus of the U.S. research. Blundell and MaCurdy (1999), Slemrod (1998), Saez (1999) and Auten and Carroll (1999, henceforward AC) either are surveys or include brief surveys and provide many other references. The size of this elasticity helps determine the social marginal cost per dollar revenue raised by the personal income tax system and hence is important in determining both the optimal tax mix and the optimal size of the public sector. The potential response in household taxable income to changes in personal income tax rates includes the standard focus of introductory economics classes such as changes in labor supply and saving behavior. However as particularly emphasized by Slemrod (1998), a number of other types of responses are likely important. Some of these are described in everyday parlance as "tax planning" and include changes in the timing of income realization as well as tax avoidance by such measures as changing the form of compensation or the type of assets held. Responses may also include tax evasion as well as a variety of behavioral changes that may change the timing and nature of tax deductions and tax credits.

The nature of Canadian tax reform is discussed in Section 2. Section 3 describes the data: the availability of a very large taxfiler data set for Canada is one of the motivations for this research. 
The empirical model is discussed in Section 4. Section 5 provides the empirical results. To anticipate this section, using a method and specification very similar to that used by AC for the United States, we estimate that the tax-price elasticity is relatively small in Canada. However, when we focus on selfemployment income, the labour income of seniors or on individuals with high incomes, it appears as if the response to taxes may be larger. Naturally any differences between results for Canada and results for other countries do not necessarily imply that the labor supply or saving behavior of Canadians is different: the differences could be as a result of differences in personal income tax systems. Section 6 concludes.

\section{Tax Reform in Canada}

The Canadian personal income tax system is individually based in the sense that there is no such thing as a joint return by spouses: all those with significant income must file singly. However, in some cases individuals with low income spouses can claim a deduction for that spouse, and the spouse will not file. Both the federal government and each province and territory have a personal income tax; for every province and territory except Quebec, the provincial/territorial basic personal income tax is a given percentage of the federal tax, although this percentage varies by province and over time. (For example basic provincial personal income tax as a percentage of basic federal tax in 1986 ranged from a low of $43.5 \%$ in Alberta to a high of $60 \%$ in Newfoundland, with a rate of $50 \%$ in the largest province, Ontario. By 1989 these rates were 46.5\%, 61\% and 52\% respectively.) As a rough approximation, therefore, total marginal tax rates are about $50 \%$ greater than federal marginal tax rates. In every province and territory besides Quebec, filing for both federal and provincial personal income tax is done at the same time using the same package of forms. Both the federal and provincial tax systems, however, have their own individual surtaxes, reliefs and credits. In Quebec, provincial income tax is 
filed separately from federal income tax and even basic provincial income tax is not a direct function of federal income tax.

While changes in Canadian personal income tax provisions are frequent both at the federal and provincial level, the tax reform of 1988 was unusually substantial. There were two main types of changes. First, as shown in Table 1, the number of tax brackets changed from eleven to four, changing the marginal federal tax rates for some individuals by reasonably large amounts (especially recalling that, because of the dependence of most provincial tax rates on federal tax rates, marginal total tax rates changed by about 50\% more). Unlike the 1986 United States tax reform, there were no comparable changes to corporation income tax. Second, the definition of taxable income was changed as a number of exemptions and deductions that were previously subtracted in the calculation of taxable income were either eliminated or more commonly converted to nonrefundable tax credits. Each tax deduction and exemption had saved a qualifying taxpayer with a high marginal tax rate more dollars than a qualifying taxpayer with a low marginal tax rate but the new tax credits represented approximately the same absolute dollar tax saving to most taxpayers. As well, the fraction of capital gains and losses included in income tax was changed from one-half to two-thirds. These changes mean that the columns of Table 1 are not comparable and there is no one-to-one correspondence between income level and changes in either marginal tax rates or taxes paid. However, the basic patterns over the years 1986 to 1989 are illustrated in the Appendix for two very uncomplicated taxfilers, a single taxpayer with only standard deductions/exemptions and a similar childless taxpayer with a spouse who earns no income.

Such calculations make two points clear. First, because of the phasing in and out of special tax reliefs in Ontario and other provinces, marginal tax rates for those with low incomes change dramatically over relatively small ranges of income. Because of this and also because social assistance may create earning disincentives unrelated to the personal income tax, we will exclude low income 
taxpayers from this analysis. Second, unlike the U.S. reforms where marginal personal income tax rates fell at virtually all income levels (although by varying amounts), in Canada marginal tax rates tended to fall for those at low, moderately low and high incomes. For those with middle incomes the pattern was more mixed, with some increases and some reductions.

Our analysis will be over the period 1986 to 1989 . The starting year was chosen to minimize anticipatory effects, given the 1988 tax reform was announced in 1987. The end year was chosen because 1990 was the beginning of a serious and persistent recession in Canada and there were also major tax changes in 1991 (especially involving tax-deferred saving as well as the introduction of a value added tax). Using the 1989 endpoint avoids these problems, although it is likely that our analysis does not capture all the long-run effects of the reform.

\section{The Data}

The Canadian experience may be particularly useful to study because the available data set is large. The Small Area and Administrative Data Division of Statistics Canada maintains the Longitudinal Administrative Database (LAD), a panel data file of information as provided by taxfilers on their personal income tax returns. Both personal and family income and taxation information is kept for each individual in the panel. The panel started with the 1982 tax year and is updated each year. Each year's sample is representative of the set of all taxfilers plus those who did not file but are included on the return of a spouse who did file. Once selected, taxfilers appear in the database every subsequent year that they appear on a tax return. Because the LAD is a $10 \%$ sample and currently about 20 million Canadians file a personal income tax return, the resulting sample is substantial.

As mentioned our target period will be 1986 to 1989 . We include only individuals who filed in both years, without changing province of residence or marital status. We exclude residents of Quebec, because the Quebec provincial income tax system is so different, but we include residents of all 
other provinces and territories. As mentioned we also exclude low income individuals who may be subject to high marginal tax rates over short ranges of the income schedule: specifically we exclude anyone who did not pay at least $\$ 625$ basic federal tax in 1986 or its rough real equivalent of $\$ 700$ in 1989. We consider two age groups, those who were always between 25 and 64 years of age during this period and those who were always over 64 years of age during this period. ${ }^{1}$

\section{The Empirical Model}

Changes in the marginal tax rate may influence reported taxpayer income in many ways (see e.g. Feldstein (1995) or Slemrod (1998). Following AC we try to estimate the effect through a model that includes among its independent variables the log of (one minus the marginal tax rate $(M T R))$, a variable henceforward called the log of the "tax price":

$$
Y_{i t}=\mu_{i}+\gamma_{t}+\beta \log \left(1-M T R_{t}\right)+X_{i}^{\prime} \alpha_{t}+\varepsilon_{i t}
$$

where $Y_{i t}$ will be a measure for individual $i$ at time $t$ of income or some other variable that may be a function of changes in tax rates, $\mu_{i}$ is the fixed effect for individual $i$ and $\gamma_{t}$ is a pure time effect. $X_{i}^{\prime}$ is a row vector of observations on individual $i$ on variables that do not vary over time but may have a timevarying effect on $Y_{i t}$ (an effect summarized by $\alpha_{t}$ ) and $\varepsilon_{i t}$ is a random error.

Again following the approach of AC we take the 1989 less 1986 first difference to obtain:

$$
\Delta Y_{i t}=\Delta \gamma_{t}+\beta \Delta \log \left(1-M T R_{t}\right)+X_{i}^{\prime} \Delta \alpha_{t}+\Delta \varepsilon_{i t}
$$

where $\Delta$ denotes the first difference.

Following $\mathrm{AC}$ our $X_{i}^{\prime}$ includes the log of initial income, the log of initial capital income, the initial age and the initial age-squared, the initial number of children and marital status (which

\footnotetext{
${ }^{1}$ Auten and Carroll (1999) also exclude those who change marital status as well as a number of low income individuals. They also exclude those who are not always over age 24 but put the upper age limit on their sample at 59 rather than the 64 we use for our younger sample. They do not exclude those who changed state of residence as we exclude those who changed province of residence.
} 
remains unchanged), where in our case "initial" means 1986. AC argue that the initial income variable allows for reversion-to-the-mean effects, that the initial capital income variable is a proxy for financial wealth (which may affect a taxpayer's ability to adjust asset holdings and labor market arrangements as a response to changes in tax rates), and that age, age-squared, number of children and marital status variables allow for life cycle and household effects. We use a self-employment dummy to replace AC's "entrepreneurship" dummy and we include provincial and territorial dummies for Canada while AC used regional dummies for the United States. AC also include a "Children away from home" dummy and (in some sets of estimates) occupational dummies. We cannot estimate these dummy variables accurately and do not include them. We note that in AC, the inclusion of occupational dummies made little difference to the coefficients of other variables.

Turning to the variables in somewhat more detail, $Y_{i t}$ is a gross income variable defined as income reported for taxation purposes adjusted to (i) reflect actual dividend income rather than an adjusted dividend income that is used for tax purposes (ii) remove capital gains (iii) include refundable tax credits and (iv) include nontaxable transfers such as workers' compensation and social assistance income. Recall the 1986 value of this variable is also on the right-hand side as part of $X_{i .}$ In other regressions we use different dependent variables to try to focus on different components of income.

Capital income is defined as investment plus dividend income. Regular employment income is from employment that is not self-employment. For these and other variables that can equal zero in the sample, $\$ 1$ is added to all values so that logarithms may be taken. Most of the other variables are self-explanatory except for the self-employment dummy, which equals one if 1986 selfemployment income exceeds $\$ 500$ and is zero otherwise. Self-employment income includes net business, commission, farming, fishing, partnership and professional income. The means and standard deviations of all variables (some of which will be discussed in Section V) are defined in Table 2. 
We must calculate a marginal tax rate variable because it is not included in the LAD set. It is defined as the additional provincial and federal personal income tax that would be paid on one dollar of labor income including all surtaxes and reliefs. Our measure is approximate only because it does not include possible additional payments on unemployment insurance, Canada Pension Plan (the public pension program) or any secondary effects through the medical expense deduction or the charitable contribution deduction/credit (both of which may in some cases be limited by taxable income) or foreign taxes paid.

\section{Results}

A difficulty with estimating equation (2) is the endogeneity of the marginal tax rate variable. The marginal tax rate can change both because of the legislation and because of changes in taxable income that push taxpayers into lower or higher tax brackets. Hence changes in the marginal tax rate variable may be correlated with the disturbances in equation (2). If ordinary least squares estimates were employed, the estimates would be inconsistent. Hence again following AC, we employ an instrumental variables technique, treating the actual marginal tax rate variable (the log of the tax-price) as endogenous and using as an instrument the log of the tax-price calculated with the "exogenous" marginal tax rate (EMTR), the marginal tax rate that would have been applicable had the taxpayer's real income not changed. The results of this procedure are given in the first column of Table 3 . While the estimated coefficients of the variables are not always numerically close to those of AC for the United States, the signs are identical. The key coefficient, that of the log of the tax price, is about .25 , much smaller than the AC preferred estimate of approximately $.6{ }^{2}$ This in turn is smaller than other

\footnotetext{
${ }^{2}$ As noted, AC limit their sample to individuals age 25 to 55 but we use age 25 to 61 . As a check, we redid the estimates restricting the sample only to those 25 to 55 in 1986 and obtained results for all coefficients very close numerically to those above, with the coefficient of the log of the tax price 0.23 . We also wondered whether the self-employment dummy variable adequately captured variations in self-employment activity across individuals.
} 
estimates based on periods of U.S. tax reform such as an estimate of approximately .8 due Navratil (1995) and the still higher values of from 1 to about 3 estimated by Lindsey (1987) and Feldstein (1995). Of course as Slemrod (1998) emphasizes, there is no necessary inconsistency between our estimates for Canada and the higher values estimated for the United States: different tax systems have different tax price elasticities.

We now consider different dependent variables. First we consider taxable income. However because some tax deductions changed to tax credits during this period, 1986 taxable income is adjusted so that it is on the same basis as 1989 taxable income, i.e. those 1986 deductions that would not have applied in 1989 (because they had been converted to tax credits) are added back into 1986 taxable income. We call the result taxable income adjusted for credits and it can be seen that the results are very close to those based on gross income with the tax-price elasticity still smaller. As the gross income definition does not include capital gains but the taxable income definition does, the closeness of these results suggests that the change in capital gains treatment between 1986 and 1989 is not driving these results.

Another possible dependent variable is work income defined as regular employment (that is employment that is not self-employment) income plus self-employment income. It can be seen that it appears to have been much more responsive to the change in tax rates than the other income definitions, with an estimated tax-price elasticity of .9 . When the dependent variable is broken up into its components, the estimated tax rate sensitivity of regular employment income is low while the estimated tax-price elasticity of self-employment income exceeds one. As a sensitivity check, we respecified the work income, regular employment income and self-employment income equations so each would have

\footnotetext{
Accordingly we added the $1986 \log$ of self-employment income to the regression and found its coefficient to be small, positive and significantly different from zero, but that no other estimated coefficient changed substantially and the estimated tax price elasticity is 0.22 .
} 
the log of 1986 regular employment income and the log of 1986 self-employment income as right hand side variables (with the log of 1986 work income deleted from the work income equation). The key results from this were that the coefficients of the log of regular employment income and selfemployment income were almost identical in the work income equation, the estimated tax-price elasticity for regular employment income was unchanged, but the estimated tax-price elasticity for selfemployment income fell to just over .7. Nonetheless, taken as a whole, the results are consistent with the view that the tax-price responsiveness of self-employment income is significantly greater than that of regular employment income. This result seems natural given that there is much more flexibility with self-employment income to evade taxes or to pursue tax planning strategies that change the timing or type of income received.

In Table 4, we repeat the previous analysis for the senior population, that is for all those over age 64 in 1986. For the first two columns it can be seen that the results are very comparable to those of Table 3. But from the third column it can be seen that the tax-price elasticity estimate for work income is very high. For the senior population, where presumably the option of retiring or reducing labor hours substantially is a frequently considered option, the estimates from our approach suggest that regular employment income is more sensitive to the tax price than is self-employment income. ${ }^{3}$

In an earlier "difference-in-difference" approach to tax rate responsiveness in Canada, Sillamaa (1998) found evidence of different responses to the tax reform change by income level. Hence in Table 5, we restrict our sample only to those with high income, defined as gross income in excess of $\$ 75,000$ in 1986 . Not all these individuals were in the top bracket in 1986 (if so there would have been no variation in our instrument and the estimation would not have succeeded) but most such individuals

\footnotetext{
${ }^{3}$ Here when we pursued the robustness checks involving adding the log of 1986 self-employment income or the $\log$ of 1986 regular employment income or both to various equations as described above and in footnote 2 , there was almost no numerical change in any of the coefficient estimates.
} 
are in the top two 1986 brackets. Hence the estimation essentially compares the behavior of the top bracket and "almost-top-bracket" taxpayers. (This is in a limited sense in the spirit of Eissa (1995) where the difference-in-difference approach is applied to very high household income married women taxpayers with a control group of high household income married women taxpayers. Feldstein (1995) also uses this approach although he also considers a moderate income group who experiences substantial marginal tax rate reductions.) The first column estimates come from a sample of all high income taxpayers age 25 to 61 in 1986, the second column comes from a sample of all high income taxpayers age 65+ in 1986 and the third column uses only married women, age 25 to 61 in $1986^{4}$. Gross income tax-price elasticity estimates are about 1.3, 1.9 and .9 respectively. Navratil (1995) finds evidence that tax-price responses are higher for high income individuals for both episodes of United States tax reform he studies.

These estimates are much higher than the comparable estimates in Tables 3 and 4. Lindsey (1985) offers the approximation that the tax rate that maximizes revenue is the reciprocal of one plus the tax-price elasticity. Using that approximation, these estimates suggest that for a population of these higher income individuals, revenue would be maximized by a marginal tax rate of about $45 \%$ for the working age population, which is slightly less than the top marginal rate at the time. For seniors, the maximum-revenue marginal rate is estimated to be about $35 \%$ and for married women, just over $50 \%$. As Lindsey, AC and Feldstein (1999) all point out, these approximations depend on the assumption that the tax system is proportional; with a progressive tax system the revenue-maximizing tax rate is lower.

However these results must be treated with caution. First, they are based on much smaller sample sizes than those in Tables 3 and 4 and indeed the tax-price elasticity estimate for married women is barely significant at the 5 per cent level. Second, the earlier results of overall sensitivity are being

\footnotetext{
${ }^{4}$ This is not comparable to Eissa (1995) because these women earn this income individually. (As mentioned,
} 
driven by the response of high income individuals even though some lower income individuals received marginal tax rate reductions as well. Hence when we lowered the cutoff from $\$ 75,000$ first to $\$ 60,000$ and then to $\$ 50,000$, the tax-price elasticity estimates corresponding to the first column fell to 0.99 and then to 0.80 . So while our results are consistent with a substantial tax-price sensitivity by high income individuals (who initially had the highest marginal tax rate), they are also consistent with any other factor that led to a particular increase in gross incomes for those in the highest bracket. Third, as Slemrod (1996, 1998) emphasizes, high income individuals may have particular access to various sorts of mechanisms for changing the form in which income is taken (e.g. fringe benefits, stock plans) or changing the timing of income receipt. ${ }^{5}$ Hence it is possible the estimation is picking up at least in some degree an intertemporal response that is larger in the short run than in the long run.

\section{Conclusions}

We have estimated the response of gross income to a significant change in marginal tax rates that occurred in Canada in 1988 using a large sample of Canadian taxfilers. Using specifications and estimation strategies broadly comparable to those of Auten and Carroll (1999) for the United States, our estimates for Canada suggest a tax-price elasticity for working-age individuals of about .25 or less than half the Auten and Carroll estimate and less than one-quarter of the lower bound Feldstein estimate. As has been emphasized by Slemrod (1998), there is no reason that these estimates need be

\footnotetext{
Canadian personal income tax filing is individual and never joint.)

${ }^{5}$ Goolsbee (1997) finds evidence that high-income U.S. executives do shift income intertemporally in this manner but that most of the effects do not persist beyond the year the tax changes take effect. Veall (2000) finds no evidence that Canadian tax reform induced shifts in tax deferred saving behavior.
} 
similar even if individuals in the two countries exhibit identical behavioral responses, because the tax systems in the two countries are different. When we divide the income into components, we find some evidence that reported self-employment income is more sensitive to the tax-price, as might be expected given that self-employment allows more opportunities for tax evasion and for tax avoidance or intertemporal tax shifting. When we restrict our attention to seniors, the gross income tax-price elasticity estimate does not shift much but there is some evidence that the work income component may be more tax sensitive, perhaps because those seniors who remain in the work force have more options for changing their labour force hours (including either retiring or postponing retirement). Finally, when we restrict our sample to higher income individuals of either working age or age 65 and over, there is some evidence of tax-price elasticities of one or greater.

This last result is among the most interesting and we note that Auten and Carroll obtain estimates in this range when they do not control for the overweighting of high income returns in their sample. Feldstein (1999) argues that the lower estimates they obtain when they do control for this overweighting might underestimate the effect of a proportional tax change if high-income individuals have higher behavioral responses; he further presents a United States calculation where the overall revenue effects and the deadweight loss of simulated proportional tax change are dominated by the responses of high-income taxpayers. Those with high incomes (as well as the self-employed and seniors with labour income) might have more flexibility to change their incomes, although some of this may be tax planning or intertemporal shifting rather than changes in investment behavior or labour supply. Yet the finding of a concentrated gross-income response among high-income taxpayers highlights a possible fragility in our identification of these effects. Trends unrelated to taxation that increased the relative incomes of those towards the top of the income distribution (such as skill-biased technological change or increasing international openness that provides relative benefits to the skilled and mobile) could 
contribute to our findings. ${ }^{6}$ Hence while our results are consistent with a high response by those with high incomes, methods that exploit other tax rate variation would be helpful to confirm or refute these estimates. These methods may include those that exploit the variation in tax rates due to tax bracket creep (Saez, 1999), other methods that use longer periods of time such as those of Navratil (1995) or Blundell, Duncan and Meghir (1998) (although these methods bring their own challenges, such as finding a suitable control period for the former or finding some replacement for the education variable that the latter use as an instrument, given that education is not observed in our data) or perhaps simply exploiting time series/cross section variation in federal and provincial income tax changes.

In summary, our results based on the Canadian 1988 tax reform suggest a smaller overall tax price response in Canada than has been estimated for the United States. However our results are consistent with a tax price response by the self-employed and those with high incomes that is much larger than the overall response. Because there are other possible explanations especially for this latter result, further research that exploits other types of tax rate variation would be useful.

\footnotetext{
${ }^{6}$ Similarly our results for high income seniors could be due to high-income seniors postponing their retirement relative to lower-income seniors.
} 
Acknowledgements: This is a revision of an earlier paper of the same title written solely by MaryAnne Sillamaa and based on her research at Statistics Canada in summer, 1998. Thanks are due to Emile Tompa, James Poterba and an anonymous referee for their comments on that version. The subsequent revision was made possible through access to the Longitudinal Administrative Database through Statistics Canada's collaboration with SEDAP (the research program on the Social and Economic Dimensions of an Aging Population). Our thanks go to Doug Norris, Linda Standish, Pat Grainger and Paul Francoeur of Statistics Canada for facilitating these arrangements and to Ed Malota and especially Eric Olson for computational assistance. Parts of the revision were presented by the second author at seminars at the University of Alberta, the University of Guelph, Laval University and the State University of New York at Buffalo and thanks are due to participants there for valuable comments; comments of Linda Standish, Jan Patenaude and other colleagues at Statistics Canada are also gratefully acknowledged. The Social Sciences and Humanities Research Council of Canada provided financial support both to SEDAP and to the second author. Any opinions and conclusions expressed are those of the authors and should not be attributed to Statistics Canada.

\section{References}

Auerbach, A. J., Slemrod, J., 1997. The economic effects of the Tax Reform Act of 1986. Journal of Economic Literature 35, 589-632.

Auten, G., Carroll, R., 1999. The effect of income taxes on household income. Review of Economics and Statistics 81 (4), 681-693.

Blundell, R., Duncan, A., Meghir, C. 1998. Estimating labor supply responses using tax reforms. Econometrica 66 (4), 827-861.

Blundell, R., MaCurdy, T. 1999. Labor supply: a review of alternative approaches. In: Ashenfelter, O., Card, D. (Eds.), Handbook of Labor Economics, Volume 3., Elsevier, Amsterdam.

Eissa, N., 1995. Taxation and labor supply of married women: the Tax Reform Act of 1986 as a natural experiment. NBER Working Paper No. 5023, National Bureau of Economic Research, Cambridge. 
Feldstein, M., 1995. The effect of marginal tax rates on taxable income: a panel study of the 1986 Tax Reform Act. Journal of Political Economy 103, 551-572.

Feldstein, M., 1999. Tax avoidance and the deadweight loss of the income tax. Review of Economics and Statistics 81, 674-680.

Goolsbee, A., 1997. What happens when you tax the rich? NBER Working Paper No. 6333, National Bureau of Economic Research, Cambridge.

Lindsey, L. 1987. Individual taxpayer response to tax cuts: 1982-1984. Journal of Public Economics 33, 173-206.

Navratil, J., 1995. Essays on the impact of marginal tax rate reductions on the reporting of taxable income on individual income tax returns. Ph.D. dissertation, Harvard University.

Saez, E., 1999. The effect of marginal tax rates on income: a panel study of 'bracket creep'. NBER Working Paper No. 7367, National Bureau of Economic Research, Cambridge.

Sillamaa, M.-A., 1998a. The effect of marginal tax rates on taxable income: a panel study of the 1988 tax flattening in Canada. mimeograph.

Sillamaa, M.-A., 1998b. Testing some theorems about taxation and labor supply using a panel of Canadian taxpayers. mimeograph.

Slemrod, J. (Ed.), 1990. Do Taxes Matter? The Impact of the Tax Reform Act of 1986. MIT Press, Cambridge.

Slemrod, J., 1996. High-income families and the tax changes of the 1980s: the anatomy of behavioral response. In: Feldstein, M., Poterba J.M. (Eds.), Empirical Foundations of Household Taxation, University of Chicago Press, Chicago.

Slemrod, J., 1998. Methodological issues in measuring and interpreting taxable income elasticities. National Tax Journal 51 (4), 773-788.

Veall, M., 2000. Did tax flattening affect RRSP contributions? mimeograph. 


\begin{tabular}{|c|c|c|c|}
\hline \multicolumn{4}{|c|}{ Table 1: Changes in federal tax brackets due to the tax reform of 1988} \\
\hline 1987 taxable income & & 8 taxable inco & \\
\hline limit (Cdn\$) & 1987 tax rate $(\%)$ & limit $(\mathbf{C d n} \$)$ & 1988 tax rate $(\%)$ \\
\hline 1320 & 6 & & 17 \\
\hline 2639 & 16 & & 17 \\
\hline 5279 & 17 & & 17 \\
\hline 7918 & 18 & & 17 \\
\hline 13,197 & 19 & & 17 \\
\hline 18,476 & 20 & & 17 \\
\hline 23,755 & 23 & & 17 \\
\hline- & 23 & 27,500 & 17 \\
\hline 36,952 & 25 & - & 26 \\
\hline- & 25 & 55,000 & 26 \\
\hline 63,347 & 30 & above & 29 \\
\hline above & 34 & - & 29 \\
\hline
\end{tabular}




\begin{tabular}{|l|c|c|c|c|}
\hline \multicolumn{5}{|c|}{ Table 2: Means and Standard Deviations of Variables } \\
\hline & \multicolumn{2}{|c|}{ Age 25-61 in 1986 } & \multicolumn{2}{c|}{ Age 65+ in 1986 } \\
\hline & Mean & S.d. & Mean & s.d. \\
\hline$\Delta \log$ gross taxable income & 0.0648 & 0.3396 & -0.0075 & 0.2998 \\
\hline$\Delta \log$ taxable income adjusted for credits & 0.1037 & 0.3656 & 0.0405 & 0.3458 \\
\hline$\Delta \log$ work income & -0.1468 & 1.7205 & -0.7413 & 2.7549 \\
\hline$\Delta \log$ regular employment income & -0.1897 & 2.2036 & -0.6536 & 2.6190 \\
\hline$\Delta \log$ self-employment income & 0.0565 & 1.8975 & -0.1229 & 1.4332 \\
\hline$\Delta \log$ (1-marginal tax rate) & -0.0129 & 0.1014 & -0.0047 & 0.1022 \\
\hline$\Delta \log$ (1- exogenous marginal tax rate) & -0.0266 & 0.1284 & 0.0029 & 0.1428 \\
\hline $\log$ 1986 gross income & 10.2541 & 0.4894 & 10.1999 & 0.5059 \\
\hline $\log 1986$ taxable income adjusted for credits & 10.1146 & 0.4870 & 10.0941 & 0.5181 \\
\hline log of 1986 work income & 9.9087 & 1.5098 & 2.1873 & 3.9911 \\
\hline log 1986 regular employment income & 9.4944 & 2.4334 & 1.6294 & 3.5517 \\
\hline log 1986 self-employment income & 0.6723 & 2.4565 & 0.6324 & 2.3955 \\
\hline log of 1986 capital income & 3.5249 & 3.4218 & 8.2557 & 2.2238 \\
\hline age in 1986 & 40 & 10.0050 & 72 & 5.6949 \\
\hline age in 1986 squared & 1700 & 847.6205 & 5200 & 850.8803 \\
\hline self-employment dummy & 0.0677 & 0.2512 & 0.0703 & 0.2557 \\
\hline number of children & 1.2142 & 1.1887 & 0.0799 & 0.3457 \\
\hline marital status & 0.7794 & 0.4147 & 0.6240 & 0.4844 \\
\hline change in self-employment & 0.0066 & 0.2252 & -0.0126 & 0.1939 \\
\hline change in number of children & -0.0417 & 0.8100 & .0039 & 0.3421 \\
\hline count & 475090 & & 46460 \\
\hline
\end{tabular}




\begin{tabular}{|c|c|c|c|c|c|}
\hline \multicolumn{6}{|c|}{$\begin{array}{c}\text { Table 3: Instrumental Variable Estimates, Population 25-61 in } 1986 \\
\text { Dependent Variable: Change in income }\end{array}$} \\
\hline & \multicolumn{5}{|c|}{ Definition of income used: } \\
\hline & Gross & $\begin{array}{c}\text { Taxable } \\
\text { (Adjusted for } \\
\text { Credits) }\end{array}$ & Work & $\begin{array}{c}\text { Regular } \\
\text { Employment }\end{array}$ & Self-employment \\
\hline Intercept & $\begin{array}{c}2.1914 \\
(142.901) \\
\end{array}$ & $\begin{array}{c}2.2795 \\
(138.600) \\
\end{array}$ & $\begin{array}{l}-0.9377 \\
(20.479) \\
\end{array}$ & $\begin{array}{l}-1.4031 \\
(24.414)\end{array}$ & $\begin{array}{l}0.3441 \\
(6.819)\end{array}$ \\
\hline$\Delta \log (1-\mathrm{MTR})$ & $\begin{array}{c}0.2525 \\
(15.017) \\
\end{array}$ & $\begin{array}{l}0.1353 \\
(7.658)\end{array}$ & $\begin{array}{c}0.9178 \\
(10.563) \\
\end{array}$ & $\begin{array}{l}0.2166 \\
(1.950)\end{array}$ & $\begin{array}{c}1.1235 \\
(10.962)\end{array}$ \\
\hline $\begin{array}{l}\log \text { of } 1986 \\
\text { income }\end{array}$ & $\begin{array}{c}-0.2187 \\
(170.018) \\
\end{array}$ & $\begin{array}{c}-0.2364 \\
(169.618) \\
\end{array}$ & $\begin{array}{c}-0.3300 \\
(199.746) \\
\end{array}$ & $\begin{array}{c}-0.3127 \\
(201.804) \\
\end{array}$ & $\begin{array}{c}-.0732 \\
(13.877) \\
\end{array}$ \\
\hline $\begin{array}{l}\log \text { of } 1986 \\
\text { capital income }\end{array}$ & $\begin{array}{c}0.0052 \\
(32.914) \\
\end{array}$ & $\begin{array}{c}0.0083 \\
(50.532) \\
\end{array}$ & $\begin{array}{l}-0.0174 \\
(23.376) \\
\end{array}$ & $\begin{array}{l}-0.0252 \\
(26.586) \\
\end{array}$ & $\begin{array}{c}0.0126 \\
(14.919) \\
\end{array}$ \\
\hline age in 1986 & $\begin{array}{c}0.0097 \\
(21.150) \\
\end{array}$ & $\begin{array}{c}0.0137 \\
(28.280) \\
\end{array}$ & $\begin{array}{c}0.2533 \\
(113.730) \\
\end{array}$ & $\begin{array}{c}0.2631 \\
(93.023) \\
\end{array}$ & $\begin{array}{c}-0.0054 \\
(2.154) \\
\end{array}$ \\
\hline $\begin{array}{l}\text { age in } 1986 \\
\text { squared }\end{array}$ & $\begin{array}{l}-0.0002 \\
(30.824) \\
\end{array}$ & $\begin{array}{l}-0.0002 \\
(37.375) \\
\end{array}$ & $\begin{array}{c}-0.0035 \\
(133.282) \\
\end{array}$ & $\begin{array}{c}-0.0036 \\
(108.111) \\
\end{array}$ & $\begin{array}{c}0.00001 \\
(0.358) \\
\end{array}$ \\
\hline $\begin{array}{l}\text { self-employ } \\
\text { dummy }\end{array}$ & $\begin{array}{c}0.0355 \\
(18.121) \\
\end{array}$ & $\begin{array}{l}0.02961 \\
(14.316) \\
\end{array}$ & $\begin{array}{l}0.0859 \\
(9.052) \\
\end{array}$ & $\begin{array}{c}-0.7114 \\
(47.526) \\
\end{array}$ & $\begin{array}{l}-1.9166 \\
(37.941) \\
\end{array}$ \\
\hline \# of children & $\begin{array}{l}0.0036 \\
(7.383) \\
\end{array}$ & $\begin{array}{c}0.0051 \\
(10.045) \\
\end{array}$ & $\begin{array}{c}0.0352 \\
(15.251) \\
\end{array}$ & $\begin{array}{l}0.0290 \\
(9.861) \\
\end{array}$ & $\begin{array}{l}0.0210 \\
(7.911) \\
\end{array}$ \\
\hline marital status & $\begin{array}{c}0.0171 \\
(13.411) \\
\end{array}$ & $\begin{array}{l}0.0120 \\
(8.880) \\
\end{array}$ & $\begin{array}{l}0.0077 \\
(1.242) \\
\end{array}$ & $\begin{array}{l}-0.0115 \\
(1.467) \\
\end{array}$ & $\begin{array}{l}0.0298 \\
(4.256) \\
\end{array}$ \\
\hline
\end{tabular}




\begin{tabular}{|c|c|c|c|c|c|}
\hline \multicolumn{6}{|c|}{$\begin{array}{c}\text { Table 4: Instrumental Variable Estimates, Population 65+ in } 1986 \\
\text { Dependent Variable: Change in income }\end{array}$} \\
\hline & \multicolumn{5}{|c|}{ Definition of income used: } \\
\hline & Gross & $\begin{array}{c}\text { Taxable } \\
\text { (Adjusted for } \\
\text { Credits) }\end{array}$ & Work & $\begin{array}{c}\text { Regular } \\
\text { employment }\end{array}$ & Self-employment \\
\hline Intercept & $\begin{array}{l}0.8382 \\
(4.466) \\
\end{array}$ & $\begin{array}{l}0.3654 \\
(1.746) \\
\end{array}$ & $\begin{array}{l}-15.7725 \\
(10.997) \\
\end{array}$ & $\begin{array}{l}-16.5604 \\
(12.906) \\
\end{array}$ & $\begin{array}{l}1.7914 \\
(2.301)\end{array}$ \\
\hline$\Delta \log (1-\mathrm{MTR})$ & $\begin{array}{r}0.2934 \\
(7.857) \\
\end{array}$ & $\begin{array}{l}0.2748 \\
(6.423) \\
\end{array}$ & $\begin{array}{l}2.4408 \\
(8.134) \\
\end{array}$ & $\begin{array}{l}1.7638 \\
(6.657) \\
\end{array}$ & $\begin{array}{l}0.6369 \\
(3.810) \\
\end{array}$ \\
\hline $\begin{array}{l}\text { log of } 1986 \\
\text { income }\end{array}$ & $\begin{array}{l}-0.1965 \\
(53.684)\end{array}$ & $\begin{array}{c}-0.2418 \\
(56.629) \\
\end{array}$ & $\begin{array}{c}-0.4317 \\
(119.840) \\
\end{array}$ & $\begin{array}{c}-0.4510 \\
(143.682) \\
\end{array}$ & $\begin{array}{l}-0.3112 \\
(24.805) \\
\end{array}$ \\
\hline $\begin{array}{l}\text { log of } 1986 \\
\text { capital income }\end{array}$ & $\begin{array}{c}0.0174 \\
(24.624) \\
\end{array}$ & $\begin{array}{c}0.0195 \\
(24.485) \\
\end{array}$ & $\begin{array}{l}-0.0537 \\
(10.120) \\
\end{array}$ & $\begin{array}{l}-0.0521 \\
(11.015) \\
\end{array}$ & $\begin{array}{c}-0.0058 \\
(1.999) \\
\end{array}$ \\
\hline age in 1986 & $\begin{array}{l}0.0245 \\
(5.013) \\
\end{array}$ & $\begin{array}{l}0.0465 \\
(8.472) \\
\end{array}$ & $\begin{array}{c}0.4248 \\
(11.034) \\
\end{array}$ & $\begin{array}{c}0.4441 \\
(12.888) \\
\end{array}$ & $\begin{array}{l}-0.0432 \\
(2.060) \\
\end{array}$ \\
\hline $\begin{array}{l}\text { age in } 1986 \\
\text { squared }\end{array}$ & $\begin{array}{l}-.0001 \\
(4.416) \\
\end{array}$ & $\begin{array}{l}-0.0003 \\
(7.363) \\
\end{array}$ & $\begin{array}{l}-0.0027 \\
(10.646) \\
\end{array}$ & $\begin{array}{l}-0.0029 \\
(12.416) \\
\end{array}$ & $\begin{array}{l}0.0003 \\
(1.916) \\
\end{array}$ \\
\hline $\begin{array}{l}\text { self-employ } \\
\text { dummy }\end{array}$ & $\begin{array}{l}-0.0212 \\
(3.759) \\
\end{array}$ & $\begin{array}{l}-0.0107 \\
(1.685) \\
\end{array}$ & $\begin{array}{c}1.5200 \\
(29.883) \\
\end{array}$ & $\begin{array}{c}-0.7114 \\
(47.526) \\
\end{array}$ & $\begin{array}{l}0.1579 \\
(1.363) \\
\end{array}$ \\
\hline $\begin{array}{l}\text { number of } \\
\text { children }\end{array}$ & $\begin{array}{c}-0.0101 \\
(2.459) \\
\end{array}$ & $\begin{array}{l}-0.0074 \\
(1.587) \\
\end{array}$ & $\begin{array}{l}0.1375 \\
(4.240) \\
\end{array}$ & $\begin{array}{l}0.0290 \\
(9.861) \\
\end{array}$ & $\begin{array}{l}0.0517 \\
(2.878) \\
\end{array}$ \\
\hline marital status & $\begin{array}{l}0.0182 \\
(6.033) \\
\end{array}$ & $\begin{array}{l}0.0174 \\
(5.112) \\
\end{array}$ & $\begin{array}{l}0.0687 \\
(2.930) \\
\end{array}$ & $\begin{array}{l}-0.0115 \\
(1.467) \\
\end{array}$ & $\begin{array}{l}0.0261 \\
(2.022) \\
\end{array}$ \\
\hline
\end{tabular}




\begin{tabular}{|c|c|c|c|}
\hline \multicolumn{4}{|c|}{$\begin{array}{l}\text { Table 5: Instrumental Variable Estimates, Taxpayers with Gross Income in Excess of } \$ 75 \mathrm{~K} \\
\text { Dependent Variable: Change in gross income }\end{array}$} \\
\hline & $24<1986$ age $<62$ & 1986 age $>64$ & $\begin{array}{l}\text { married women, } \\
24<1986 \text { age }<62\end{array}$ \\
\hline Intercept & $\begin{array}{l}1.7594 \\
(7.642)\end{array}$ & $\begin{array}{l}-3.0981 \\
(1.789)\end{array}$ & $\begin{array}{l}1.8470 \\
(2.056)\end{array}$ \\
\hline$\Delta \log (1-\mathrm{MTR})$ & $\begin{array}{l}1.2963 \\
(12.715)\end{array}$ & $\begin{array}{l}1.9305 \\
(7.058)\end{array}$ & $\begin{array}{l}0.9121 \\
(1.970)\end{array}$ \\
\hline $\begin{array}{l}\text { log of } 1986 \text { gross } \\
\text { income }\end{array}$ & $\begin{array}{l}-0.2161 \\
(14.631)\end{array}$ & $\begin{array}{l}-0.1774 \\
(5.873)\end{array}$ & $\begin{array}{l}-0.2643 \\
(4.311)\end{array}$ \\
\hline $\begin{array}{l}\text { log of } 1986 \text { capital } \\
\text { income }\end{array}$ & $\begin{array}{l}0.0095 \\
(4.605)\end{array}$ & $\begin{array}{l}0.0402 \\
(4.537)\end{array}$ & $\begin{array}{l}0.0032 \\
(0.374)\end{array}$ \\
\hline age in 1986 & $\begin{array}{l}0.0264 \\
(3.588)\end{array}$ & $\begin{array}{l}0.1110 \\
(2.452)\end{array}$ & $\begin{array}{l}0.0483 \\
(1.743)\end{array}$ \\
\hline age in 1986 squared & $\begin{array}{l}-0.0004 \\
(4.647)\end{array}$ & $\begin{array}{l}-0.0007 \\
(2.363)\end{array}$ & $\begin{array}{l}-0.0006 \\
(1.966)\end{array}$ \\
\hline $\begin{array}{l}\text { self-employment } \\
\text { dummy }\end{array}$ & $\begin{array}{l}0.0353 \\
(2.620)\end{array}$ & $\begin{array}{l}-0.0600 \\
(1.807)\end{array}$ & $\begin{array}{l}0.0417 \\
(0.753)\end{array}$ \\
\hline number of children & $\begin{array}{l}0.0221 \\
(4.214)\end{array}$ & $\begin{array}{l}-0.0200 \\
(0.584)\end{array}$ & $\begin{array}{l}0.0049 \\
(0.230)\end{array}$ \\
\hline marital status & $\begin{array}{l}0.0135 \\
(0.704)\end{array}$ & $\begin{array}{l}0.0459 \\
(1.435)\end{array}$ & n.a. \\
\hline No. of observations & 12610 & 1900 & 895 \\
\hline \multicolumn{4}{|c|}{$\begin{array}{l}\text { The endogenous right hand side variable is } \Delta \log (1-\mathrm{MTR}) \text { and the instrument is } \Delta \log \text { (1-EMTR), } \\
\text { where EMTR is the marginal tax rate change that would have occurred if real gross income had } \\
\text { remained constant. Absolute values of t-statistics are in parentheses. For the second column, the } \\
\text { number of selected individuals in the two territories (Yukon and the Northwest Territories) } \\
\text { became sufficiently small that Statistics Canada removed those individuals from this regression } \\
\text { calculation to preserve confidentiality and individuals from Yukon have been eliminated from the } \\
\text { third column for the same reason. }\end{array}$} \\
\hline
\end{tabular}




\section{Appendix}

The following graphs correspond to a taxfiler from Ontario who is in the first case single and in the second case is married to a spouse with zero income, otherwise has no dependents, is of age less than 65, has no pension income, has no disability, is not paying tuition or pursuing further education, has medical expenses less than 3\% of net income (and also less than 1517 current dollars in 1989), no charitable or similar donations and no foreign taxes paid or participation in tax-favoured investments. Federal and provincial income taxes are included with all applicable surtaxes and reliefs. (It is the phasing out of a provincial relief to low income taxpayers that leads to the spike in each case.) Unemployment insurance and Canada Pension Plan premiums are not included as taxes.

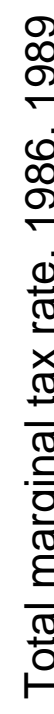

Total tax rates, single

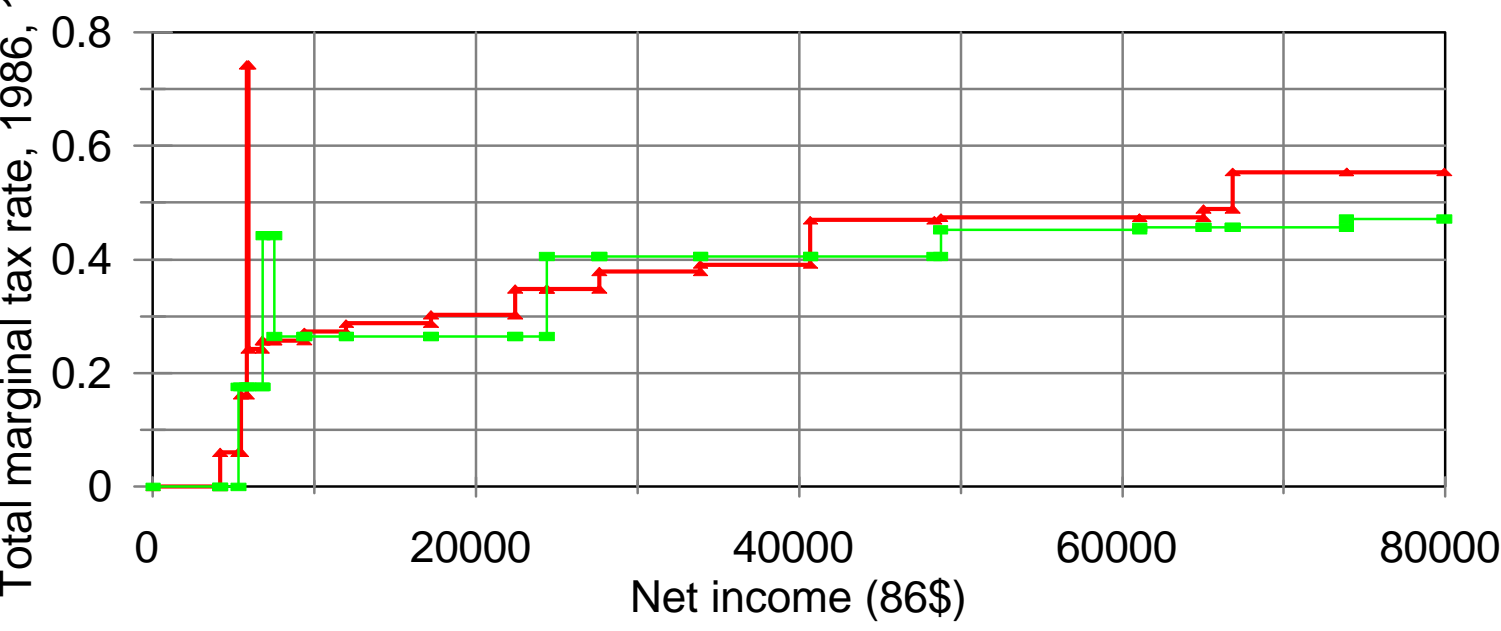

$\simeq 1986-1989$ 


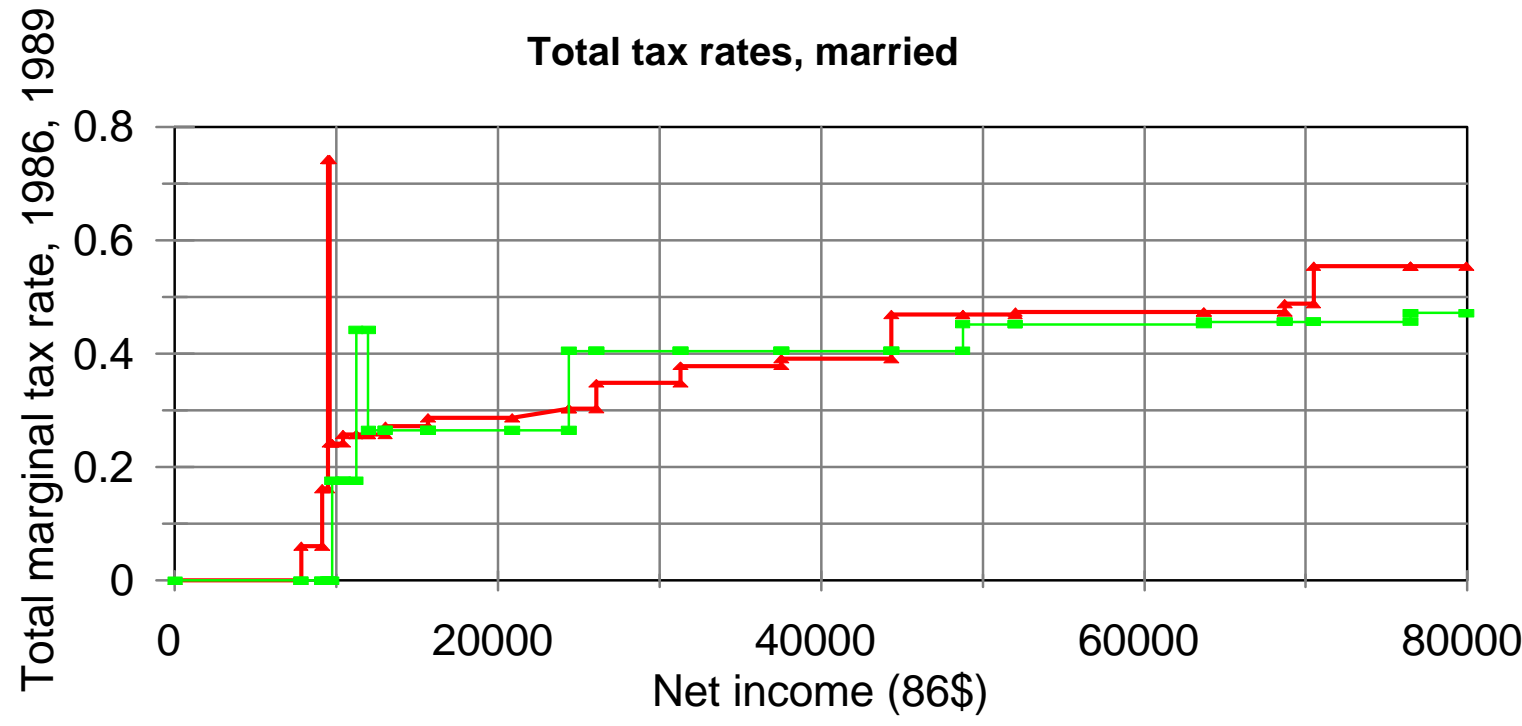

Total tax rates, married

$\stackrel{\circ}{\leftarrow}$

$1986-1989$ 
QSEP RESEARCH REPORTS - Recent Releases

Number

Title

Authors

No. 337: Energy Use in the Commercial Sector: Estimated Intensities and Costs for Canada Based on US Survey Data

F.T. Denton

D.C. Mountain

B.G. Spencer

No. 338: A Bayesian Approach for Measuring Economies of Scale with Application to Large Canadian Banks

M.W.L. Chan

D. Li

D.C. Mountain

No. 339: Economic Costs of Population Aging

F.T. Denton

B.G. Spencer

No. 340: Population Aging and Its Economic Costs: A Survey of the Issues and Evidence

F.T. Denton

B.G. Spencer

No. 341: How Much Help is Exchanged in Families? Towards an Understanding of Discrepant Research Findings

No. 342: Did Tax Flattening Affect RRSP Contributions?

C.J. Rosenthal

L.O. Stone

M.R. Veall

No. 343: Families as Care-Providers Versus Care-Managers? Gender and Type of Care in a Sample of Employed Canadians

C.J. Rosenthal

A. Martin-

Matthews

No. 344: $\quad$ Alternatives for Raising Living Standards

W. Scarth

No. 345: Mixed Estimation When the Model And/Or Stochastic Restrictions are Nonlinear

F.T. Denton

No. 346: A Model of Energy Demand in the U.S. Commercial Sector with Declining Rate Schedules

F.T. Denton

D.C. Mountain

B.G. Spencer

No. 347: Projections of the Population and Labour Force to 2046: Canada

F.T. Denton

C.H. Feaver

B.G. Spencer

No. 348: Projections of the Population and Labour Force to 2046: The Provinces and Territories

F.T. Denton

C.H. Feaver

B.G. Spencer

No. 349: Location of Adult Children as an Attraction for Black and White Elderly Migrants in the United States

K.-L. Liaw

W.H. Frey

J.-P. Lin

No. 350: The Effects of Drug Subsidies on Out-of-Pocket

T.F. Crossley

Prescription Drug Expenditures by Seniors: Regional

P. Grootendorst

Evidence from Canada

S. Korkmaz 
M.R. Veall

No. 351: Describing Disability among High and Low Income Status Older Adults in Canada

P. Raina

M. Wong

L.W. Chambers

M. Denton

A. Gafni

No. 352: Some Demographic Consequences of Revising the

F.T. Denton Definition of 'Old' to Reflect Future Changes in Life Table Probabilities

B.G. Spencer

No. 253: The Correlation Between Husband $₹$ and Wife Education: Canada, 1971-1996

L. Magee

J. Burbidge

L. Robb

No. 254: The Effect of Marginal Tax Rates on Taxable Income:

M.-A. Sillamaa A Panel Study of the 1988 Tax Flattening in Canada 